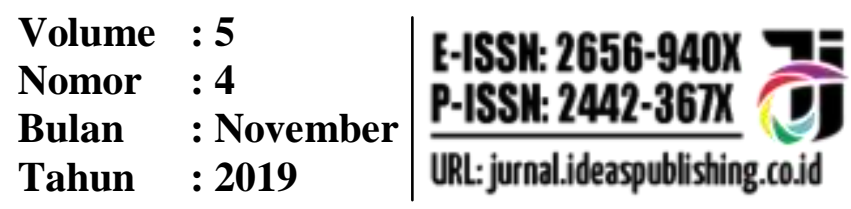

\title{
Upaya Meningkatkan Aktivitas dan Hasil Belajar Matematika Berbasis PBL
}

\author{
Ernie Arsyad \\ SMKS Almamater Telaga Kabupaten Gorontalo \\ surel: erniearsyad68@gmail.com \\ DOI: 10.32884/ideas.v5i4.232
}

\begin{abstract}
Abstrak
Penelitian ini bertujuan untuk menerapkan metode pembelajaran problem based learning (PBL) untuk meningkatkan aktivitas dan hasil belajar siswa pada pembelajaran matematika. Jenis penelitian ini adalah penelitian tindakan kelas (PTK). Subjek penelitiannya adalah siswa kelas XI DPIB SMKS Almamater Telaga Provinsi Gorontalo. Hasil penelitian ini menunjukkan penerapan metode pembelajaran problem based learning (PBL) dapat meningkatkan aktivitas dan hasil belajar siswa pada pembelajaran matematika. Peningkatan hasil belajar siswa dapat dilihat dari siklus I yaitu 14 siswa atau 60,84\% yang dinyatakan mampu dan 8 siswa atau 34,78\% belum mampu. Pada siklus II terjadi peningkatan yaitu ada 23 siswa atau $100 \%$ yang dinyatakan mencapai ketuntasan.
\end{abstract}

Kata kunci: aktivitas, hasil belajar, problem based learning

\section{Pendahuluan}

Pembelajaran matematika selama ini masih didominasi oleh pembelajaran konvensional. Siswa diposisikan sebagai objek pembelajaran. Siswa dianggap tidak tahu atau belum mengerti apa-apa, sementara guru memposisikan diri sebagai seorang yang mempunyai pengetahuan. Oleh karena itu, guru terkesan menggurui dan memiliki otoritas tertinggi dalam proses pembelajaran.

Saat ini, pembelajaran matematika yang diberikan di sekolah merupakan bentuk yang sudah jadi. Bentuk yang sudah jadi ini umumnya tidak melibatkan siswa dalam proses belajar mengajar, sehingga masih relatif rendah dalam berusaha menemukan sendiri konsep dari materi yang diajarkan guru.

Proses pembelajaran matematika harus melibatkan proses dalam bentuk aktivitas berpikir dalam diri siswa secara aktif dengan mengembangkan kemampuan kognitif merek. Hal ini disebabkan perkembangan kognitif sebagai penentu kecerdasan intelektual anak terus berkembang seiring dengan proses pendidikan. Selain itu, juga dipengaruhi oleh faktor perkembangan fisik terutama otak secara biologis.

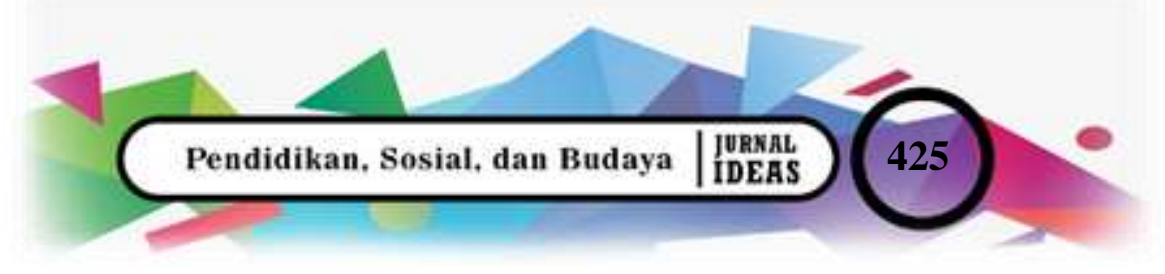




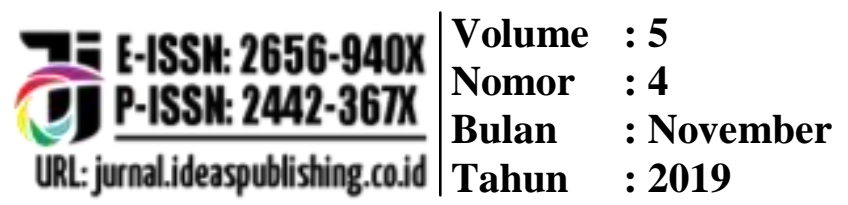

Perkembangan selanjutnya yang berkaitan dengan kognitif adalah cara mengelola atau mengatur kemampuan kognitif tersebut dalam merespon situasi atau permasalahannya. Tentunya, aspek-aspek kognitif tidak dapat berjalan sendiri secara terpisah tetapi perlu dikendalikan atau diatur sehingga jika seseorang akan menggunakan kemampuan kognitifnya maka perlu kemampuan untuk menentukan dan pengatur aktivitas kognitif apa yang akan digunakan.

Kenyataan di lapangan siswa hanya menghapal konsep dan kurang mampu menggunakan konsep tersebut jika menemui masalah dalam kehidupan nyata yang berhubungan dengan konsep yang dimiliki (Trianto, 2011). Lebih jauh lagi bahkan siswa kurang mampu menentukan masalah dan merumuskannya. Aktivitas pembelajaran ataupun pengajaran masih rendah, apalagi jika dikaitkan dengan pemahaman siswa mengenai pemahaman materi yang diajarkan. Pemahaman yang dimaksud ini adalah pemahaman siswa terhadap dasar kualitatif mengenai fakta-fakta yang saling berkaitan dengan kemampuannya untuk menggunakan pengetahuan tersebut dalam situasi baru. Sebagian besar siswa kurang mampu menghubungkan antara apa yang mereka pelajari dengan bagaimana pengetahuan tersebut akan dimanfaatkan/ diaplikasikan pada situasi baru.

Pemilihan model pembelajaran berbasis masalah didasarkan pada karakteristik model pembelajaran itu sendiri yang lebih menekankan pada kemampuan berpikir kritis siswa. Selain itu, melalui proses analisis pemecahan masalah, siswa juga dapat menemukan konsep, prinsip, dan berbagai pengalaman belajar sehingga menjadikan siswa lebih aktif, kritis menganalisis masalah, dan kreatif dalam mengikuti pelajaran matematika.

\section{Metode}

Penelitian ini dilaksanakan di SMKS Almamater Telaga Provinsi dalam waktu tiga bulan, mulai dari bulan Agustus 2017 sampai dengan bulan Oktober 2017. Subjek penelitian adalah siswa kelas XI DPIB SMKS Almamater Telaga Provinsi Gorontalo pada semester 1 tahun pelajaran 2017/2018 dengan jumlah siswa sebanyak 23 siswa 


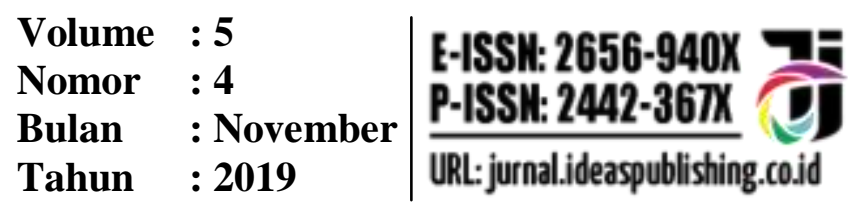

Penelitian yang dilaksanakan adalah penelitian tindakan kelas (classroom action research) yang dilaksanakan minimal dua siklus. Setiap siklus pada penelitian tindakan terdiri dari empat tahap, yaitu 1) Perencanaan, 2) Pelaksanaan, 3) pengamatan, 4) Refleksi.

Teknik pengumpulan data yang digunakan dalam penelitian ini adalah lembar observasi dan tes hasil belajar. Kriteria keberhasilan tindakan ditetapkan berdasarkan ketuntasan belajar yang ditetapkan oleh sekolah dan berdasarkan pertimbangan peneliti. Adapun kriteria keberhasilan tindakan tersebut sebagai berikut.

1. Apabila $\geq 85 \%$ siswa tuntas menurut kriteria ketuntasan minimal (KKM) yang telah ditetapkan oleh sekolah, yaitu 68,00.

2. Aktivitas rata-rata siswa secara individu mencapai kriteria baik, yaitu berada pada kisaran skor $24 \leq x \leq 30$.

\section{Hasil dan Pembahasan \\ Hasil}

Penelitian tindakan kelas melalui penerapan metode pembelajaran problem based learning (PBL) di kelas XI DPIB SMKS dilaksanakan dalam 2 siklus. Setiap siklus terdiri dari empat tahap, yaitu: 1) refleksi awal, 2) perencanaan, 3) pelaksanaan, 4) observasi. Masing-masing tahap akan diuraikan sebagai berikut.

\section{Kondisi Awal}

Berdasarkan hasil wawancara dan observasi pembelajaran di kelas, dapat dikemukakan gambaran umum permasalahan yang dihadapi guru dalam proses pembelajaran matematika di kelas XI DPIB SMKS melalui tabel berikut ini.

\section{Tabel 1}

Rekapitulasi Hasil Tes Formatif Kondisi Awal

\begin{tabular}{clrr}
\hline No. & Kriteria Penilaian & Perolehan Nilai & Ket. \\
\hline 1. & Nilai Rata-Rata & 60.00 & \\
2. & Siswa Tuntas & 6 & \\
3. & Persentase & 26.09 \\
4. & Siswa Belum Tuntas & 17 \\
5. & Persentase & 73.91 \\
6. & Ketuntasan Klasikal & 26.09 & \\
\hline
\end{tabular}

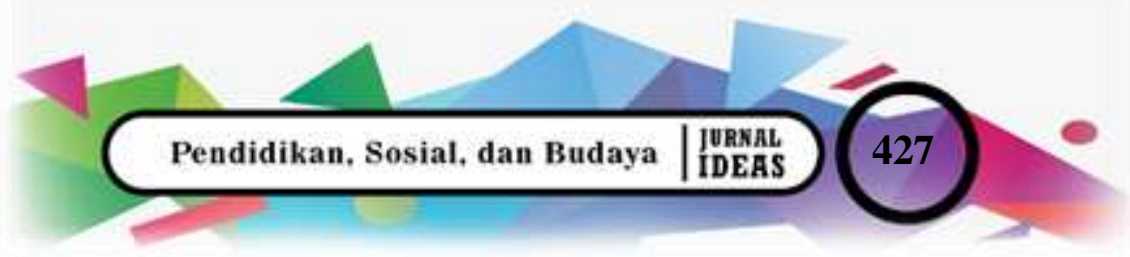




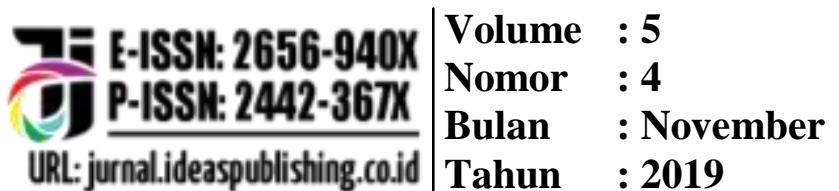

Dari tabel di atas dapat dijelaskan bahwa nilai rata-rata sebesar 60,00 dengan siswa tuntas sebesar 26,09\% atau 6 siswa; siswa belum tuntas atau mendapat nilai kurang dari KKM sebesar 68,00 sebanyak 17 siswa atau 73,91\%; dan angka ketuntasan klasikal sebesar 26,09\%.

Tabel 2

Rekapitulasi Hasil Observasi Aktivitas Siswa dalam Kegiatan Pembelajaran Kondisi Awal

\begin{tabular}{cccc|c}
\hline Kriteria Skor & $\begin{array}{c}\text { Jumlah } \\
\text { Siswa }\end{array}$ & Persentase & $\begin{array}{c}\text { Kriteria } \\
\text { Penilaian }\end{array}$ & Ket \\
\hline $\mathbf{1 0} \leq \mathbf{x}<\mathbf{1 7}$ & 3 & 13.04 & Kurang Aktif & Belum Tuntas \\
\hline $\mathbf{1 7} \leq \mathbf{x}<\mathbf{2 4}$ & 12 & 52.17 & Cukup Aktif & Belum Tuntas \\
\hline $\mathbf{2 4} \leq \mathbf{x} \leq \mathbf{3 0}$ & 8 & 34.78 & Aktif & Tuntas \\
\hline
\end{tabular}

Dari penjelasan tabel di atas dapat disimpulkan bahwa aktivitas belajar siswa masih rendah. Hal tersebut dibuktikan dengan hanya terdapat 8 siswa atau 34,78\% yang dinyatakan tuntas karena masuk dalam kriteria penilaian aktif, sedangkan sisanya yaitu 12 siswa atau 52,17\% dalam kriteria cukup aktif, dan kurang aktif sebanyak 3 siswa atau $13,04 \%$.

\section{Siklus Pertama}

Pada siklus 1 dilaksanakan 2 pertemuan. Alokasi waktu untuk masing-masing pertemuan adalah $2 \times 45$ menit.

a. Perencanaan

Perencanaan tindakan siklus I dirancang berdasarkan hasil refleksi awal saat peneliti melaksanakan observasi awal dan wawancara terhadap guru matematika. Adapun rencana pelaksanaan siklus I sebagai berikut.

1) Mempersiapkan perangkat pembelajaran.

a) Menyiapkan silabus kelas XI DPIB SMKS semester ganjil

b) Menyusun rencana pembelajaran yang berorientasi pada metode Problem Based Learning.

c) Membuat lembar kegiatan siswa. 


\section{Volume : 5 \\ Nomor : 4 \\ Bulan : November \\ Tahun : 2019

d) Menyiapkan lembar observasi aktivitas siswa.

e) Membentuk soal tes siklus I dan rubric penilaiannya.

2) Membentuk kelompok siswa dalam kegiatan belajar. Siswa kelas XI DPIB SMKS yang jumlah seluruhnya ada 23 siswa dibagi dalam 11 kelompok. Setiap kelompok terdiri dari 2 siswa dan ada 1 kelompok yang beranggotakan 3 orang, kelompok siswa pada siklus I berdasarkan pada posisi duduk yang berdekatan.

b. Pelaksanaan Tindakan Siklus I

Pada tahap pelaksanaan tindakan dan observasi, peneliti yang bertindak sebagai guru melaksanakan tindakan sesuai dengan langkah langkah pembelajaran dengan model Problem Based Learning seperti pada RPP yang telah disusun. Berikut ini rekapitulasi hasil tes formatif siklus I.

\section{Tabel 3}

\section{Rekapitulasi Hasil Tes Formatif Siklus Pertama}

\begin{tabular}{clrr}
\hline No. & Kriteria Penilaian & Perolehan Nilai & Ket \\
\hline 1. & Nilai Rata-Rata & 65.65 & \\
2. & Siswa Tuntas & 11 & \\
3. & Persentase & 47.83 & \\
4. & Siswa Belum Tuntas & 12 & \\
5. & Persentase & 52.17 & \\
6. & Ketuntasan Klasikal & 47.83 & \\
\hline
\end{tabular}

Dari tabel di atas dapat dijelaskan bahwa nilai rata-rata yaitu 65,65 dengan data yang menyatakan siswa tuntas sebesar 47,83\% atau 11 siswa; siswa belum tuntas atau mendapat nilai kurang dari KKM yaitu sebesar 68,00 sebanyak 12 siswa atau 52,17\%; dan angka ketuntasan klasikal sebesar $80 \%$.

Data di atas menunjukkan dalam siklus I ini hasilnya belum sesuai dengan indikator yang diharapkan yaitu minimal $85 \%$ dari jumlah seluruh siswa dinyatakan tuntas atau mendapat nilai minimal sama dengan KKM yaitu 68 . 


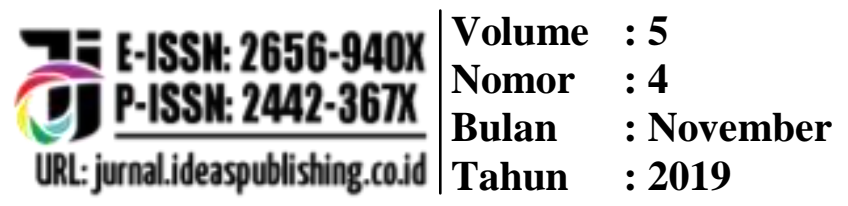

Tabel 4

Rekapitulasi Hasil Observasi Aktivitas Siswa dalam Kegiatan Pembelajaran Siklus Pertama

\begin{tabular}{ccccc}
\hline Kriteria Skor & $\begin{array}{c}\text { Jumlah } \\
\text { Siswa }\end{array}$ & Persentase & $\begin{array}{c}\text { Kriteria } \\
\text { Penilaian }\end{array}$ & Ket \\
\hline $\mathbf{1 0} \leq \mathbf{x}<\mathbf{1 7}$ & 0 & 0.00 & Kurang Aktif & Belum Tuntas \\
\hline $\mathbf{1 7} \leq \mathbf{x}<\mathbf{2 4}$ & 9 & 39.13 & Cukup Aktif & Belum Tuntas \\
\hline $\mathbf{2 4} \leq \mathbf{x} \leq \mathbf{3 0}$ & 14 & 60.87 & Aktif & Tuntas
\end{tabular}

Dari penjelasan tabel di atas dapat disimpulkan bahwa aktivitas belajar siswa sudah meningkat dari kondisi awal. Hal tersebut dibuktikan bahwa terdapat 14 siswa atau $60,87 \%$ yang dinyatakan tuntas karena masuk dalam kriteria penilaian aktif, sedangkan sisanya yaitu 9 siswa atau 39,13\% dalam kriteria cukup aktif.

c. Refleksi

Berdasarkan hasil refleksi, secara umum pelaksanaan pembelajaran matematika menggunakan problem based learning pada siklus I di kelas XI DPIB SMKS sudah berjalan dengan baik. Namun beberapa langkah belum terlaksana optimal. Langkah pertama mengorientasikan siswa pada masalah sudah berjalan dengan baik. Siswa sudah diarahkan kepada permasalahanpermasalahan yang akan didiskusikan pada pembelajaran. Langkah mengorganisasikan siswa untuk belajar sudah baik. Siswa sudah bekerja dalam kelompok-kelompok kecil. Namun dalam kelompok ada siswa yang tidak ikut bekerja dan suasana kelas ramai karena diskusi siswa yang kurang terarah dan tidak terkendali.

Langkah selanjutnya adalah membimbing penyelidikan. Pada tahap ini kegiatan belum terlaksana optimal karena keterbatasan waktu. Setiap kelompok masih banyak yang belum mandiri dan banyak bertanya kepada guru. Kendala dari siklus pertama adalah dalam mengerjakan soal masih banyak yang belum sistematis, sehingga ada langkah-langkah yang terlewati atau kadang ada langkah-langkah yang seharusnya tidak perlu dan mengakibatkan hasilnya kurang tepat. Akhirnya, kesimpulan dari hasil penyelesaian yang diperoleh juga kurang tepat. 


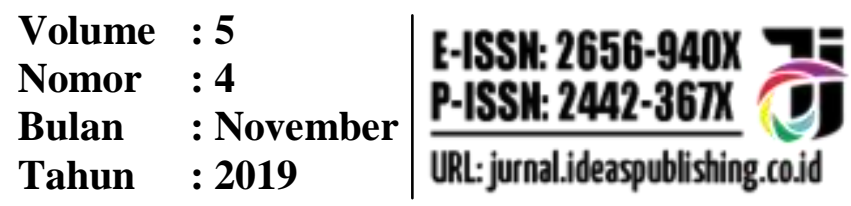

Rencana tindakan yang akan dilakukan di siklus II berdasarkan hasil refleksi dari siklus I adalah meningkatkan setiap aspek kemampuan pemecahan masalah. Hal ini dilaksanakan dengan lebih mengoptimalkan setiap langkah dari pembelajaran problem based learning. Siswa diberikan soal-soal pemecahan masalah dan didiskusikan dalam kelompok. Guru mengarahkan setiap kelompok agar lebih maksimal dalam mengikuti pembelajaran dan lebih runtut dalam menyelesaikan setiap masalah yang diberikan sesuai dengan keempat aspek dalam menyelesaikan masalah.

\section{Siklus II}

Penelitian tindakan kelas penerapan metode pembelajaran problem based learning (PBL) dilaksanakan dalam 2 kali pertemuan.

a. Perencanaan

Perencanaan tindakan siklus II dirancang berdasarkan hasil refleksi tindakan siklus kedua. Adapun rencana pelaksanaan siklus II sebagai berikut.

1) Mempersiapkan perangkat pembelajaran.

2) Menyusun Rencana Pembelajaran yang berorientasi pada metode problem based learning.

3) Membuat lembar kegiatan siswa.

4) Menyiapkan lembar observasi aktivitas siswa.

5) Membentuk soal tes siklus II dan rubik penilaiannya.

6) Pembagian kelompok pada siklus II untuk pertemuan ke-1 masih sama seperti siklus I terdiri dari 10 kelompok.

7) Refleksi tindakan berdasarkan masalah yang diperoleh pada siklus I. Berikut adalah deskripsi pembelajaran matematika yang dilaksanakan ditinjau dari karakteristik pembelajaran matematika dengan penerapan problem based learning.

a. Mengorientasikan Siswa pada Masalah

Guru mengajak siswa untuk merancang belajar sendiri dan mengumpulkan pengetahuan berkaitan dengan materi yang akan dipelajari.

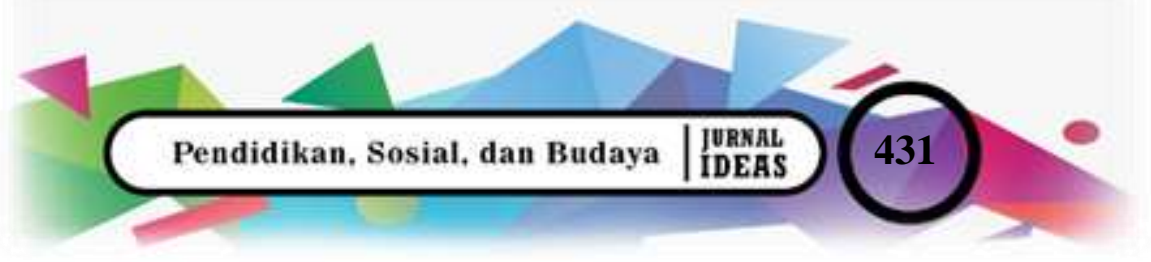




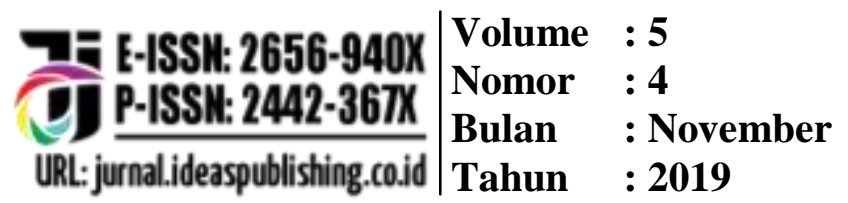

b. Mengorganisasikan Siswa untuk Belajar

Siswa dikondisikan dalam kelompok seperti pada pertemuan di siklus I. Setiap kelompok diberikan LKS. Siswa diminta untuk mencermati permasalahan pada LKS dan memulai diskusi bersama kelompoknya masing-masing untuk menyelesaikan permasalahan tersebut.

c. Membimbing Penyelidikan Individual maupun Kelompok

Siswa mulai mengerjakan bersama-sama dengan teman dalam kelompoknya. Siswa bebas mengembangkan ide mereka untuk menyelesaikan masalah. Setiap siswa dalam kelompok sudah mulai aktif untuk berdiskusi bersama teman-temannya.

d. Mengembangkan dan Menyajikan Hasil Karya

Guru mempersilakan secara sukarela kepada setiap kelompok untuk mempresentasikan hasil diskusinya di depan kelas.

e. Menganalisis dan mengevaluasi proses pemecahan masalah

Hasil diskusi yang telah dipresentasikan di depan kelas secara bersama-sama dianalisis runtutannya dalam pengerjaan, apakah setiap langkah sudah dituliskan dengan jelas, dan apakah hasil yang diperoleh sudah sesuai dengan rencana penyelesaian. Siswa diminta menanggapi hasil pekerjaan teman.

Berikut ini penjelasan mengenai hasil kegiatan pada siklus dua.

\section{Tabel 5}

\section{Rekapitulasi Hasil Tes Formatif Siklus Kedua}

\begin{tabular}{clrr}
\hline No. & Kriteria Penilaian & Perolehan Nilai & Ket \\
\hline 1. & Nilai Rata-Rata & 72.61 & \\
2. & Siswa Tuntas & 21 & \\
3. & Persentase & 91.30 & \\
4. & Siswa Belum Tuntas & 2 & \\
5. & Persentase & 8.70 & \\
6. & Ketuntasan Klasikal & 91.30 & \\
\hline
\end{tabular}




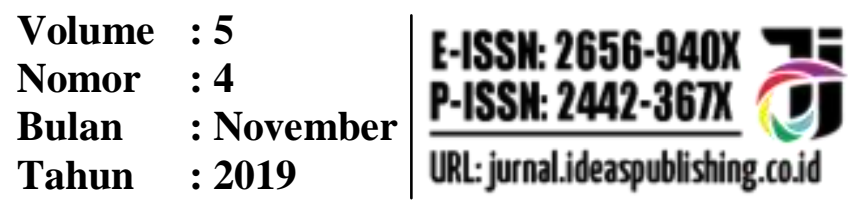

Dari tabel di atas dapat dijelaskan bahwa nilai rata-rata yaitu 72,61 dengan siswa yang tuntas sebanyak 92,30\% atau 21 siswa, siswa belum tuntas atau mendapat nilai kurang dari KKM yaitu 68,00 sebanyak 2 siswa atau 8,70\% dan angka ketuntasan klasikal sebesar 92,30\%. Data di atas menunjukkan dalam siklus II ini telah memenuhi indikator yaitu minimal 85\% dari jumlah seluruh siswa. KKM yang ditetapkan yaitu 68 , sehingga proses perbaikan pembelajaran melalui kegiatan penelitian tindakan kelas dinyatakan selesai dan tuntas pada siklus kedua.

Tabel 5

Rekapitulasi Hasil Observasi Aktivitas Siswa dalam Kegiatan Pembelajaran Siklus Kedua

\begin{tabular}{ccccc} 
Kriteria Skor & $\begin{array}{c}\text { Jumlah } \\
\text { Siswa }\end{array}$ & Persentase & $\begin{array}{c}\text { Kriteria } \\
\text { Penilaian }\end{array}$ & Ket \\
\hline $\mathbf{1 0} \leq \mathbf{x}<\mathbf{1 7}$ & 0 & 0.00 & Kurang Aktif & Belum Tuntas \\
\hline $\mathbf{1 7} \leq \mathbf{x}<\mathbf{2 4}$ & 0 & 0.00 & Cukup Aktif & Belum Tuntas \\
\hline $\mathbf{2 4} \leq \mathbf{x} \leq \mathbf{3 0}$ & 23 & 100.00 & Aktif & Tuntas \\
\hline
\end{tabular}

Dari penjelasan tabel di atas dapat disimpulkan bahwa aktivitas belajar siswa sudah meningkat dari siklus pertama. Hal tersebut dibuktikan adanya 23 siswa atau $100 \%$ yang dinyatakan tuntas karena masuk dalam kriteria penilaian aktif.

b. Refleksi Siklus II

Refleksi dilakukan oleh peneliti bersama observer. Refleksi dilakukan sejalan dengan pelaksanaan tindakan pada akhir siklus II. Berdasarkan hasil refleksi dapat dikatakan bahwa secara umum pelaksanaan pembelajaran matematika menggunakan problem based learning pada siklus II di kelas XI DPIB SMKS sudah berjalan baik dan sudah meningkat dari siklus sebelumnya. Setiap langkah dari pembelajaran problem based learning sudah terlaksana dengan baik.

Kemampuan siswa dalam mencari pemecahan masalah sudah meningkat di siklus II. Hal ini terlihat dari hasil tes kemampuan pemecahan masalah pada siklus ini. Persentase rata-rata untuk setiap aspek sudah meningkat dari siklus

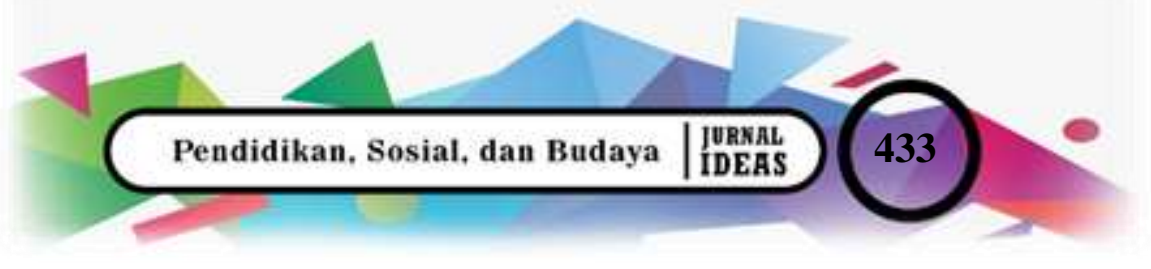




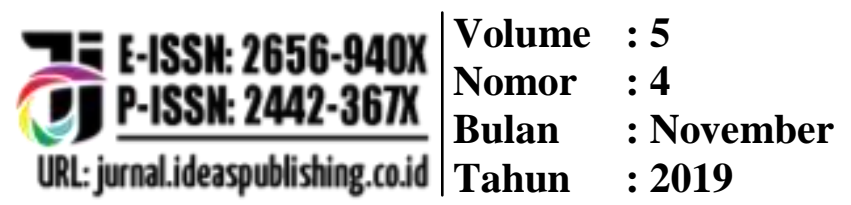

sebelumnya. Siswa sudah runtut dalam menyelesaikan masalah, sudah tepat memilih perencanaan penyelesaian dan mampu menyimpulkan dan memeriksa kembali hasil penyelesaian masalah.

Kendala dari siklus pertama adalah dalam mengerjakan soal masih banyak yang belum sistematis, sehingga ada langkah-langkah yang terlewati atau kadang ada langkah-langkah yang seharusnya tidak perlu dan mengakibatkan hasilnya kurang tepat, sehingga kesimpulan yang diperoleh juga kurang tepat. Berdasarkan refleksi tersebut dan sudah diperbaiki di siklus II, kemampuan pemecahan masalah matematika siswa sudah meningkat.

\section{Pembahasan}

Penelitian ini bertujuan untuk meningkatkan kemampuan pembelajaran matematika siswa kelas XI DPIB SMKS pada materi penyajian data dalam bentuk diagram atau grafik dengan menggunakan problem based learning. Tindakan yang diberikan kepada siswa adalah memberi kesempatan kepada siswa untuk menyelesaikan permasalahan secara berkelompok. Selain itu juga memberikan LKS untuk membantu agar siswa dapat sistematis dalam menyelesaikan masalah menuliskan apa yang diketahui, ditanyakan, ilustrasi gambar dan penyelesaian. Tindakan yang lain adalah peneliti selalu memberi nasehat agar siswa mengikuti pembelajaran dengan baik dan selalu mengingatkan untuk menyelesaikan soal pemecahan masalah dengan runtut.

Berdasarkan hasil tes evaluasi, nampak terjadi peningkatan kemampuan pemecahan masalah siswa dari siklus I ke siklus II. Hal ini dapat diketahui dari nilai rata-rata kelas yang diperoleh dari tes siklus I dan siklus II. Nilai rata-rata kelas yang diperoleh siswa pada akhir siklus I adalah 65,65 dengan kategori sedang dan meningkat menjadi 72,61dengan kategori sedang pula.

Persentase rata-rata nilai tes siswa pada siklus I ke siklus II untuk tiap-tiap indikator kemampuan pemecahan masalah juga mengalami peningkatan. Hal ini dapat dilihat pada tabel berikut ini. 


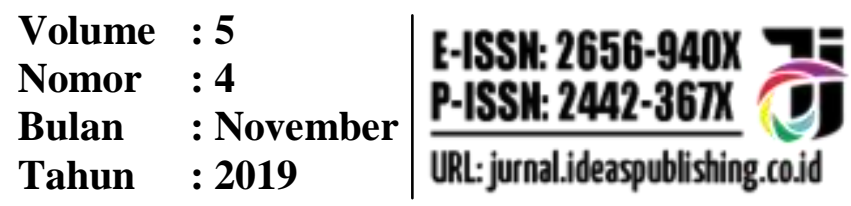

Persentase peningkatan kemampuan pemecahan masalah matematika siswa dari kondisi awal, siklus pertama ke siklus kedua jika disajikan dalam grafik adalah sebagai berikut.

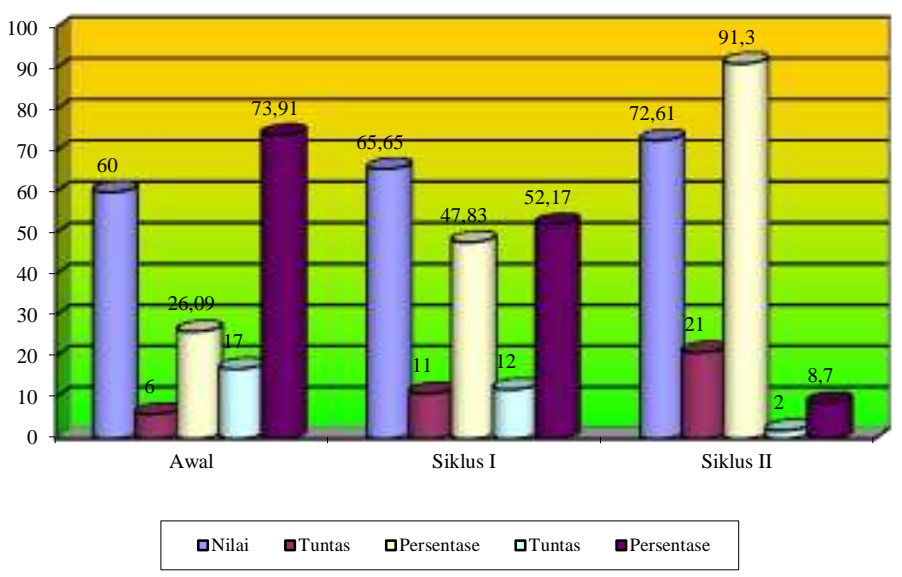

\section{Gambar 1}

Peningkatan Nilai, dan Ketuntasan Belajar Siswa pada Prasiklus, Siklus I, dan Siklus II

Dari grafik dan tabel di atas menunjukkan bahwa pelaksanaan model problem based learning pada pembelajaran matematika di kelas XI DPIB SMKS tahun pelajaran 2017-2018 dapat meningkatkan hasil belajar ini ditunjukkan dengan peningkatan ketuntasan hasil belajar per siklusnya yaitu pada kondisi awal hanya 6 siswa atau 26,09\%, siklus I ada 11 siswa atau 47,83\%, dan pada siklus II ada 21 siswa atau $91,30 \%$, hasil ini sesuai dengan indikator yang ditentukan yakni minimal siswa tuntas mencapai $85 \%$ dari jumlah seluruh siswa.

Rata-rata hasil belajar juga meningkat dari 60,00 menjadi 65,65 dan 72,61 pada siklus kedua. Hal ini menunjukkan bahwa pada siklus kedua rata-rata hasil belajar juga sudah memenuhi kriteria ketuntasan yaitu minimal sama dengan KKM sebesar 68,00.

Aktivitas belajar siswa tiap siklusnya mengalami peningkatan, hal ini di ukur dari hasil pengamatan kolaborator yang terkait dengan aktivitas siswa dalam memperhatikan keterangan guru, aktivitas siswa dalam kerja kelompok selengkapnya dapat dilihat dalam tabel berikut. 


\begin{tabular}{|c|c|}
\hline $\begin{array}{c}\text { E-ISSH: } 26 \\
\text { P-ISSN: } 26\end{array}$ & $\begin{array}{ll}\text { Volume } & : 5 \\
\text { Nomor } & : 4 \\
\text { Bulan } & : \text { November }\end{array}$ \\
\hline URL: jurnal.ideasoublishing.co.id & Tahun \\
\hline
\end{tabular}

\section{Tabel 7}

Peningkatan Aktivitas Belajar Siswa pada Prasiklus, Siklus I, dan Siklus II

\begin{tabular}{ccccc}
\hline \multirow{2}{*}{ Siklus } & \multicolumn{4}{c}{ Ketuntasan } \\
\cline { 2 - 5 } & Tuntas & $\%$ & Belum Tuntas & $\%$ \\
Awal & 8 & 34.78 & 15 & 68.18 \\
Siklus I & 14 & 60.87 & 9 & 40.91 \\
Siklus II & 23 & 100.00 & 0 & 0.00 \\
\hline
\end{tabular}

Untuk memperjelas kenaikan aktivitas belajar siswa dan penurunan aktivitas belajar siswa dapat dilihat pada diagram batang di bawah ini.

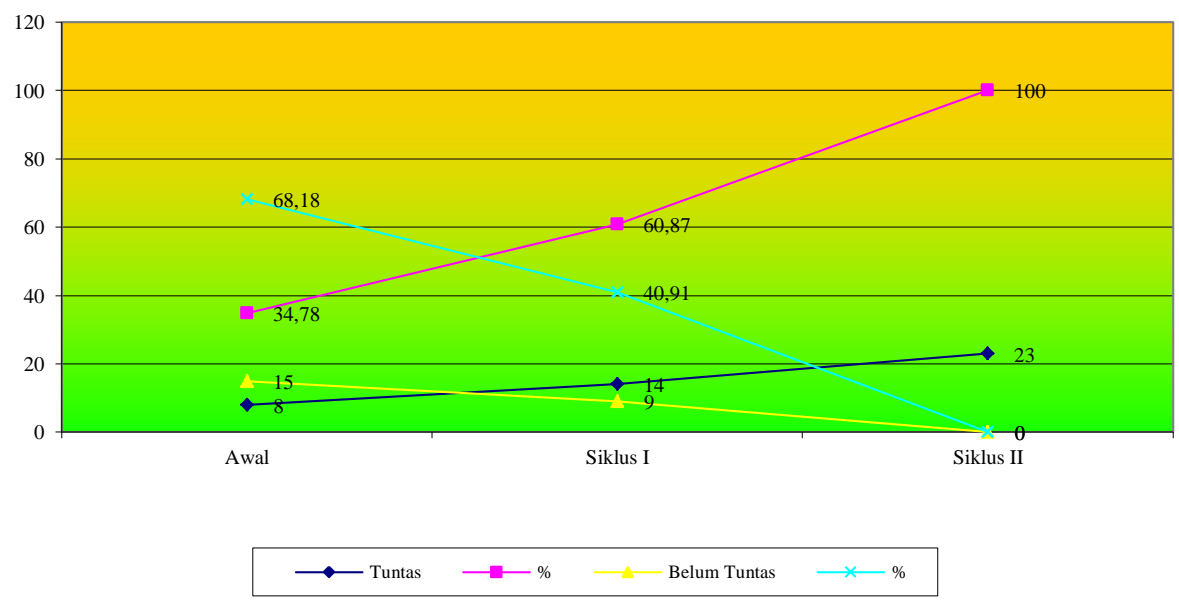

\section{Gambar 2}

\section{Peningkatan Aktivitas Belajar Siswa pada Pra Siklus, Siklus I dan Siklus II}

Dari grafik dan tabel di atas menunjukkan bahwa pelaksanaan model Problem Based Learningpada pembelajaran matematika di kelas XI DPIB SMKS Tahun Pelajaran 2017-2018 dapat meningkatkan aktivitas belajar ini ditunjukkan dengan peningkatan aktivitas belajar per siklus nya dimana pada kondisi awal hanya 8 siswa atau 34,78\%, siklus I ada 14 siswa atau $60,84 \%$, dan pada siklus II ada 23 siswa atau $100 \%$, hasil ini sesuai dengan indikator yang ditentukan yakni kategori aktif dan aktif sekali yang mencapai $85 \%$. Berdasarkan hasil di atas menunjukkan terjadi peningkatan dari pra siklus, siklus I dan siklus II, dengan kata lain tindakan peneliti dalam pelaksanaan matematika di kelas XI DPIB SMKS tahun pelajaran 2017-2018 dalam proses pembelajaran dan membimbing pada nilai ketuntasan belajar dan indikator yang diinginkan yaitu $85 \%$ tercapai. 


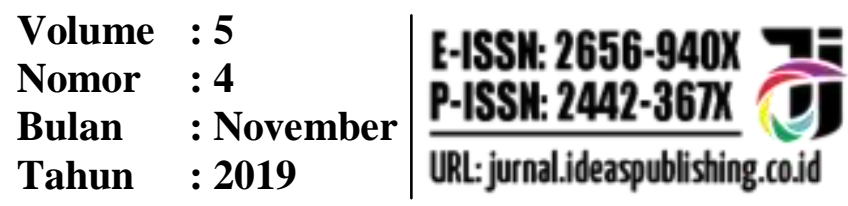

\section{Simpulan}

Hasil penelitian ini menunjukkan penerapan metode pembelajaran problem based learning (PBL) dapat meningkatkan aktivitas dan hasil belajar siswa pada pembelajaran matematika. Peningkatan hasil belajar siswa dapat dilihat dari siklus I yaitu 14 siswa atau $60,84 \%$ yang dinyatakan mampu dan 8 siswa atau $34,78 \%$ belum mampu. Pada siklus II terjadi peningkatan yaitu ada 23 siswa atau $100 \%$ yang dinyatakan mencapai ketuntasan. Kenyataan di atas didukung pula oleh peningkatan hasil belajar siswa yaitu nilai rata-rata hasil belajar terus mengalami peningkatan dari 60,00 menjadi 65,65 dan 72,61 pada siklus kedua dengan tingkat ketuntasan belajar yang juga meningkat pada setiap siklusnya, yaitu 6 siswa atau 26,09\%, siklus I ada 11 siswa atau 47,83\%, dan pada siklus II ada 21 siswa atau 91,30\%. Dari penjelasan di atas dapat disimpulkan bahwa indikator kriteria keberhasilan pembelajaran telah tercapai pada siklus kedua, sehingga pelaksanaan perbaikan pembelajaran dinyatakan selesai dan tuntas pada siklus kedua.

\section{Daftar Pustaka}

Arikunto, S., Suhardjono, \& Supardi. (2010). Penelitian Tindakan Kelas. Jakarta: Bumi Aksara.

Arikunto, Suharsimi. (2002). Prosedur Penelitian Suatu Pendekatan Praktek (Edisi Revisi V). Jakarta: Rhineka Cipta.

Dimyati \& Mudjiono. (2012). Belajar dan Pembelajaran. Jakarta: Rineka Cipta.

Ngalimun. (2013). Strategi dan Model Pembelajaran. Yogyakarta: Aswaja Pressindo.

Paizalouddin, \& Ermalinda. (2013). Penelitian Tindakan Kelas (classroom action research) Panduan Teoritis dan Praktis. Bandung: Alfabeta.

Purwanto, A. (2009). Penerapan Media Jejaring Sosial Facebook Pada Mata Kuliah Termodinamika. Journal Exacta. (VII) 2.

Ronis, D. (2001). Problem Based Learning for Math and Science. United States of America: Skylight.

Rusman. (2012). Model-model Pembelajaran Meningkatkan Profesionalisme Guru. Depok: Rajagrafindo Persada.

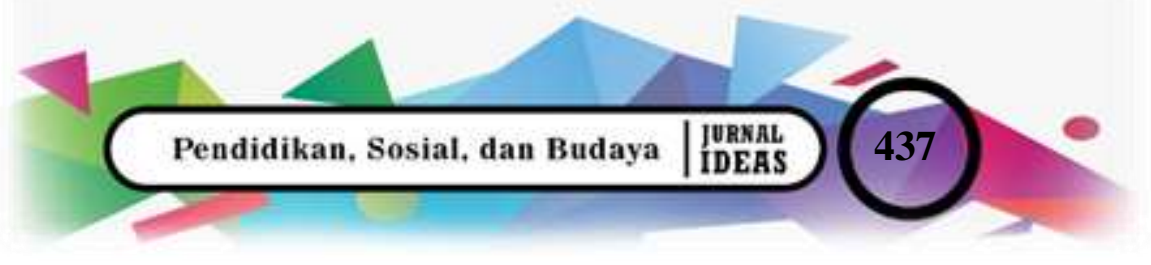




\begin{tabular}{|c|c|}
\hline $\begin{array}{c}\text { ge E-ISSH: } 2656-940 \mathrm{X} \\
\text { P-ISSN: } 2442-367 \mathrm{X}\end{array}$ & $\begin{array}{l}\text { Volume } \\
\text { Nomor } \\
\text { Bulan }\end{array}$ \\
\hline URL: jurnal.ideaspublishing.co.id & Tahun \\
\hline
\end{tabular}

Sardiman. (2012). Interaksi dan Motivasi Belajar Mengajar. Jakarta: Rajawali Pers.

Sudjana, N. (2009). Penilaian Hasil Proses belajar Mengajar. Bandung: Remaja Rosda Karya.

Suprijono, A. (2012). Cooperative Learning. Yogyakarta: Pustaka pelajar.

Trianto. (2011). Model-Model Pembelajaran Inovatif Berorientasi Konstruktivistik. Jakarta: Prestasi Pustaka. 